\title{
Professionernes etiske kerne
}

\author{
Morten Dige
}

Afdeling for Filosofi og Idehistorie, Aarhus Universitet

filmd@cas.au.dk

Soul is what is ascribed to human beings that makes them something more than just another kind of animal. Occupations could be said to have soul when they act as something more than just a technical enterprise at the service of the state, employers, and consumers. (Freidson 2003: 172)

Med udgangspunkt i en case fra socialt arbejde presenterer artiklen en "etisk loesning" af professioner og professionsudøvelse. Det gøres goeldende, at visse fag og ydelser, først og fremmest de klassiske hjolpeprofessioner, er etiske i deres kerne ved at have som formål at vorne om og fremme etiske grundvordier. Hvad der kvalificerer som etiske grundvordier søges belyst ud fra en aristotelisk etikforståelse. På baggrund heraf gøres der rede for, hvorfor de "tre au'er": autorisation, autonomi og autenticitet ifølge den etiske loesning er fundamentale forudsæetninger for etisk forsvarlig professionsudøvelse, og hvordan disse forudsæetninger kommer under pres fra en form for målrationel organisationstonkning kendt som New Public Management. Om den aktuelle "etikbølge" inden for hjoelpeprofessionerne er en del af problemet eller en del af løsningen, afhoenger i høj grad af, hvilke begreber om profession og etik der ligger bag.

Nøgleord: professionsetik, etiske grundværdier, autonomi, autenticitet

\section{English summary: The Ethical Core of Professions}

Taking a Danish case from social work as its point of departure, the article presents an "ethical reading" of professions and professional work: certain occupations and services, especially the classical helping professions, are essentially ethical by having their point and purpose in protecting and promoting core ethical values. An Aristotelian conception of ethics is offered as a qualification of what is meant by core ethical values. On this background an account is given of the reasons why the "three au's": authorization, autonomy, and authenticity are necessary conditions for ethically sound professional work and how these conditions are put under pressure by a certain end-rational organizational ideology known as New Public Management. Whether the current ethics wave in the helping professions is considered part of the problem or part of the solution depends to a large extent on which concepts of profession and ethics are invoked.

Keywords: professional ethics, core ethical values, autonomy, authenticity 


\section{"Mads-sagen"}

Socialforvaltningen i en dansk kommune blev for nogle år siden udsat for hård kritik på baggrund af sin håndtering af sager med spædbørn i udsatte familier i almindelighed og en konkret anbringelsessag om en lille dreng med dæknavnet "Mads" i særdeleshed. ${ }^{1}$ Kritikken blev især eksponeret i en dokumentarudsendelse på dansk TV 2, hvor det blev dokumenteret, at forvaltningen gennem fire måneder undlod at skride ind på trods af underretninger fra fire forskellige instanser (to børnelæger, sundhedsplejerske og plejemoderen for Mads' storebror), som samstemmende erklærede, at drengens behov for fysisk og psykisk omsorg ikke blev varetaget, fordi begge forældre udviste massive mangler i forhold til forældre-evne. Dette ytrede sig bl.a. ved, at Mads få uger efter fødslen blev indlagt på sygehus grundet underernæring. Siden gik der yderligere næsten et år, inden Mads blev anbragt hos en plejefamilie på mere permanent basis. I denne periode var han ofte kastebold mellem forældre og plejeforældre, idet plejeforældrene til enhver tid skulle bringe Mads tilbage på forældrenes anmodning - med utrygge og kaotiske forhold til følge.

Det er velkendt, at omsorgssvigt i et barns første levemåneder medfører meget stor risiko for senere udviklingsforstyrrelser, dårlig trivsel og dårlig livskvalitet. Dette bekræftes af et lignende forløb med Mads' storebror 10 år tidligere, idet det vurderes, at hans alvorlige psykiske handicaps i form ADHD og aggressiv adfærd var forårsaget og/eller forstærket af omsorgssvigt og vanrøgt i det første leveår.

Mediernes søgelys blev primært rettet mod konkrete socialrådgivere, som tilsyneladende reagerede med stor passivitet og langsommelighed på de ganske alarmerende underretninger. I det efterfølgende udredningsarbejde blev det påvist, at kommunen ikke havde efterlevet de lovfæstede krav om vurdering af forældreevne, udarbejdelse af handleplaner og opfølgning og tilsyn i forhold til udsatte børn. Spørgsmål om anbringelser skal ifølge samme lov altid baseres på en konkret helhedsvurdering og et skøn i hver enkelt sag, og her peger rapporterne på, at skønnet ikke lagde hovedvægten på barnets perspektiv (barnets tarv), men i stedet på forældrenes, hvilket er i strid med lovgivningens sigte.

Én af rapporterne afdækker den organisatoriske og politiske baggrund for socialrådgivernes arbejdsbetingelser. Her peger rådgivere og afdelingsledere på en stor medarbejderudskiftning og ikke mindst på de spareplaner for anbringelser i 2006, som konsekvent omtaltes som "Thors hammer" (opkaldt efter daværende finansminister Thor Pedersen). Besparelserne kom i forlængelse af et notat fra Socialministeriet, som angav:

Ved fastlæggelse af metoderne skal det sikres, at der i forbindelse med alle overvejelser anlægges økonomiske betragtninger. Det indebærer, at man altid skal overveje, om løsningen af de opgaver, man er forpligtet til, sker på den mest økonomiske måde. (Socialministeriet 2003: 3)

Og i forlængelse heraf, at sagsbehandlerne skal "have kendskab til og føle ejerskab for sammenhængen mellem indsats og økonomi" (Socialministeriet 2003: 7, min fremh.). En konkret konsekvens af besparelserne og notatet var, at rådgiverne blev pålagt altid at formulere et alternativ til anbringelse, dvs. også i sager, hvor helhedsvurdering af barnets tarv og det professionelle skøn klart talte for en sådan. Rådgiverne blev m.a.o. reelt sat 
under administration ved at de fik frataget bevillingskompetencer, herunder bevilling af anbringelse i plejefamilie (Kildedal 2009: 55).

Bortset fra de nævnte lovbrud er det nærliggende at karakterisere behandlingen af Mads og hans familie som både uprofessionel og etisk kritisabel. Den umiddelbare reaktion på sagen fra kommunens socialrådmand var dog at afvise kritikken med henvisning til Århus kommunes værdigrundlag:

Samlet kan man konkludere, at Socialforvaltningen har varetaget og løst opgaven om at yde særlig hjælp og støtte til en udsat familie med særligt fokus på barnets sundhed og udvikling. Værdierne troværdighed, respekt og engagement, som er vedtaget i Århus Byråd, genspejles i hele sagsgangen og -behandlingen (Århus Kommune 2008).

Jeg vil ikke her opholde mig yderligere ved sammenhængen mellem troværdighed og ulovlig sagsbehandling, men i stedet udfolde en række problematikker af mere generel karakter, som casen i mine øjne eksemplificerer. Jeg vil først kigge nærmere på sammenhængen mellem etik og professionsudøvelse i de klassiske hjælpeprofessioner og dernæst den særlige form for afprofessionalisering, som er involveret i den målrationelle organisationstænkning.

\section{Den aktuelle "etikbolge"}

Det er fristende at indlede en afdækning af professionsbegrebet med en lam kliché fra mange gymnasiestile: "Allerede de gamle grækere ...". De klassiske professioner, som kan spore deres historie tilbage til antikken, havde nemlig etiske kodekser som et konstituerende element i professionsudøvelsen. Den hippokratiske tradition i lægevidenskaben er det bedst kendte eksempel på dette. I den forstand er den såkaldte "etikbølge" inden for de professioner, jeg i det følgende vil omtale som hjolpeprofessioner, ikke udtryk for en pludselig opdagelse af etiske dimensioner i professionsudøvelsen. Det må snarere ses som forsøg på at eksplicitere og i en vis grad standardisere etiske værdier og normer. Den etiske oprustning ses typisk som et element i en professionsudvikling med den motivation at styrke professionernes strategiske position i en offentlig sektor under stadig reformering og omstilling. Som led i at styrke professionernes troværdighed og status har en lang række professionsforeninger inden for de sidste ca. 10 år udfærdiget nye værdigrundlag og etiske retningslinjer. ${ }^{2}$ De relaterede professionsuddannelser har undergået lige så radikale omorganiseringer og også her er den etiske oprustning sat ind med indførelse af etikfag og -moduler, udgivelse af lærebøger i professionsetik osv.

Behovet for den etiske oprustning skal formentlig findes i det krydspres, som professionerne udsættes for i nutidens velfærdssamfund: Én type pres kommer "nedefra" fra mere eller mindre velorganiserede grupper af patienter og klienter, mens en anden er kommet "ovenfra" fra de organisationer, moderne professioner virker i, og den politiske forvaltning, som mere eller mindre detaljeret definerer rammerne for professionsudøvelsen. Stillet over for dette krydspres kan "etikbølgen" imidlertid opleves både som en del 
af problemet og en del af løsningen. Den opleves som en del af problemet, for så vidt den ses som udefrakommende krav om etisk accountability fra de offentlige organisationers og myndighedernes side og som et element i stadig højere og stadigt mere detaljerede krav og forventninger fra forbruger-orienterede klienters side. Men den kan også ses som en reaktion eller et modsvar i forhold til disse udfordringer, en back to basics-strategi. Denne flertydighed afspejler i mine øjne en tilsvarende flertydighed i den grundlæggende forståelse af, hvad professionalisering og professionsidentitet indebærer. I back to basicsstrategien anvendes begreberne om profession og professionalisme i en italesættelse af udfordringer og problemer udløst af en række styrings-, kontrol- og ledelsesformer i den offentlige sektor, som ofte gives den vage samlebetegnelse New Public Management. Jeg skal sige en smule mere om dette i det følgende, men her blot pege på, at disse nye organiseringsformer har ført til (eller udspringer af) "a decline of trust, competence, and discretion in professional work" (Evetts 2006: 516), samtidig med at de ofte har som målsætning at "professionalisere" de ydelser, som velfærdsinstitutioner (hospitaler, skoler etc.) antages at være udbydere af (Fournier 1999).

Den antydede flertydighed rejser i sig selv et behov for en analyse og afklaring af professionsbegrebet. Mere specifikt forekommer det mig, at der er en både nærliggende og i den aktuelle situation særdeles relevant analyse, som får mindre plads, end den fortjener. Den hævder en distinkt professionslogik over for de markeds- og organisationslogikker, der præger New Public Management-bølgen. Noget sådant er langt fra ukendt i den sociologiske professionsforskning (fx Evetts 2006; 2011; Freidson 2001), men her savnes en plausibel, konkret redegørelse for det specifikt etiske i professionslogikken.

Jeg vil derfor i det følgende afsnit udgrænse et specifikt etisk professionsbegreb, som bygger på en etisk loesning af relationsprofessionerne. Den bygger på to påstande eller teser. For det første påstanden om at etiske værdier er konstituerende for visse professioner og derfor ikke meningsfuldt kan hverken forstås eller operationaliseres som udefrakommende krav eller begrænsninger, men tværtimod fungerer som en kritisk instans i forhold til eksterne krav og begrænsninger. For det andet en påstand om, at de nævnte værdier er etiske i en distinkt aristotelisk forstand. En etisk profession henter således sin raison d'etre i den opgave at værne om og fremme bestemte forudsætninger for eller elementer i et godt liv for mennesker.

\section{Det etiske professionsbegreb}

At være professionel har flere forskellige betydninger. Der kan være tale om

- at udøve et erhverv, dvs. leve af (ikke blot for) det, man beskæftiger sig med. Her er antonymet til professionel at være en amatør, dvs. alene at være motiveret af kærlighed til gerningen uden nødvendigvis at være en særligt kompetent udøver af den

- at udøve et fag, dvs. ud fra faglige standarder. Her er antonymet uprofessionel, dvs. uden ambitionen om en engageret indsats af høj kvalitet 
- at udøve et kald, dvs. at arbejde som næstekærlighedsgerning. Her er antonymet erhvervsdrivende, dvs. primært at være drevet af økonomisk vinding.

Når man traditionelt har tildelt en række hjælpe- og relationsprofessioner en særlig status, er det imidlertid klart nok udtryk for en mere fordringsfuld ide om profession og professionalisme. I den sociologiske og professionsetiske litteratur udpeges en række kriterier for professionsstatus i denne stærkere forstand. De grupperer sig typisk om de følgende (se fx Carr 2000; Hjort \& Engel 2006; Jespersen 1995):

1 Samfundsopdrag: Faget tilvejebringer en vigtig offentlig service, dvs. en samfundsmæssig opgave, der ikke uden videre kan overlades til det frie initiativ og amatøriske velgørere.

2 Ekspertise: Fagudøvelsen bygger på en specialiseret, teoretisk såvel som praktisk funderet viden.

3 Monopol: Fagudøvelsen kræver en sikring af faglighed og troværdighed og dermed en stærk organisering af uddannelse og rekruttering, som fx ytrer sig ved uddannelsesmonopol og autorisationskrav.

4 Etisk kodeks: Fagudøvelsen har en fremtrædende etisk dimension, som kalder på en professionel kodeks og giver den enkelte professionsudøver en særlig etisk legitimitet og særlige etiske forpligtelser.

5 Autonomi: Fagudøvelsen kræver en høj grad af autonomi og dømmekraft hos den individuelle professionsudøver grundet opgavernes forskellighed og foranderlighed og hos faget som helhed grundet en ofte meget åben opgavedefinition.

Den etiske loesning af professionerne udpeger det fjerde punkt som det centrale: Det vejer tungere end de øvrige, og det gennemtrænger dem på afgørende måder. Visse offentlige opgaver er vigtige, fordi de handler om at indfri en moralsk skyldighed over for borgerne (hjælpe de syge osv.); den specialiserede ekspertise er nødvendig for at kunne yde kvalificeret, professionel hjælp under forsvarlig hensyntagen til den enkelte; de høje etiske krav til professionsudøveren kræver en selektiv rekruttering og etisk dannelse (ofte via mesterlære-lignende programmer); og opgaven med at hjælpe det enkelte menneske kræver en veludviklet evne til at tage personligt ansvar og at udvise dømmekraft. ${ }^{3}$

I en række sociologiske professionsanalyser benægtes denne rangorden. Ofte udpeges en succesfuld monopoliseringsbestræbelse (bestræbelsen på markedskontrol) som konstituerende for professionerne (fx i Larson 1977), hvor det etiske kodeks primært har funktion som branding af professionen, eller professionerne ses som konstitueret af en delegeret samfundsopgave, således at samfundsopdraget motiverer de professionsetiske kodekser snarere end omvendt (Grimen 2008). Lederen af en dansk professionshøjskole udtrykker det fx således:

Brugerne af professionens ydelser skal kunne stole på, at ydelserne gives under høj moralsk integritet, men simpelthen fordi professionens udøvere er professionelle, ikke fordi de er mere moralske mennesker end andre. Arbejdsmoralen hviler på den politiske legitimitet i professionens samfunds- 
opgave, og det er således arbejdsgiverens og ikke professionsudøverens perspektiv på professionsmoralen, som er afgørende (Staugård 2009: 14).

Ifølge den etiske læsning er dette fejlagtigt. Hjælpeprofessionerne henter ikke deres primæere legitimitet i en samfundsmæssig eller institutionel opbakning, men i den etiske forpligtelse over for professionens klienter. Historisk har de netop ofte udgjort civilsamfundsmæssige institutioner og magtbaser på linje med fx fagbevægelsen og oplysningsforbundene og været en vigtig kritisk instans og modmagt i forhold til centralmagten:

Professionals, in particular, have been able to oppose unjust state or corporate actions precisely because they derive their moral legitimacy from adherence to their legitimating public pledge to serve a particular good, and not from the will of the state or the corporation or from whatever happens to be the dominant public opinion in some community at some point in time. (Koehn 1994: 158)

Eksempler på en sådan konflikt mellem samfundsopdraget og den dybere etiske legitimitet er de sovjetiske psykiatere, som mødtes med bred, international fordømmelse, fordi de lige netop tog ukritisk imod deres samfundsopdrag og "behandlede" patienter, der "led" af politisk nonkonformitet. Et andet markant eksempel er World Medical Associations resolutioner, der fordømmer enhver lægelig medvirken til dødsstraf og tortur. ${ }^{4}$ Her anses de professionsetiske værdier klart nok som en kritisk instans og et korrektiv til de opdrag, statslige myndigheder måtte finde på at pålægge professionen. I forhold til Mads-sagen kunne man tilsvarende hævde, at "professionalisme" og mangel herpå ikke alene drejer sig om, hvorvidt man lever op til en række faglige og organisatoriske standarder, men også om man forholder sig kritisk til disse i lyset af professionens særlige etiske opgave, i dette tilfælde den særlige forpligtelse i forhold til de udsatte børns tarv. Professionalisme handler set i det lys også om at udfordre praksisser, som stiller sig i vejen for en professionelt forsvarlig opgaveløsning. Dansk Socialrådgiverforening gør da også i sine etiske principper gældende, at

Socialrådgivere forventes [...] at gøre opmærksom på uligheder, social uretfærdighed og undertrykkende politiske og sociale strukturer og systemer samt at arbejde for forbedringer og om nødvendigt ændre sådanne strukturer og systemer.

Socialrådgivere har en særlig pligt til at sikre disse rettigheder for børn og andre grupper, som ikke selv er i stand til at tage vare på deres interesser (Dansk Socialrådgiverforening 2000: afsnit 2.2).

Den etiske dimensions centrale rolle kommer som sagt til udtryk ved, at man som her har kodificeret etikken i mere eller mindre eksplicitte etiske idealer og principper. Men når der tales om eller efterlyses værdigrundlag og etiske retningslinjer, er det vigtigt at gøre sig klart, hvilken funktion de skal have. Her kan der på den ene side være tale om standsetik, som angiver normer for forsvarlig faglig standard og primært tjener et defensivt sigte, nemlig at styrke fagets integritet imod fribyttere og kvaksalvere og den dårlige omtale, de kan give anledning til. I forlængelse heraf udarbejder man typisk en code of conduct, som udsteder forbud og definerer sanktioner mod karakteristiske former for grov umoralsk opførsel, som fagudøvelsen indebærer en forhøjet risiko for. Det er velkendt, at fag, som 
giver adgang til fortrolige oplysninger eller betroede midler eller tætte relationer med klienten, kan friste til, at man misbruger sin stilling til egen fordel. Populært sagt drejer det sig her om forholdsregler vedrørende sex, løgn og penge (Luban 2003). Professionsetik i denne forstand er således primært en udpegning af almengyldige normer vedrørende fortrolighed og beskyttelse af de svage, som "blot" er særligt presserende for hjælpeprofessionelle.

Man kan imidlertid også tale om professionsetik som den serlige normativitet, der knytter sig til de fag, vi kalder professioner, og specifikt om en given professions sæerlige værdigrundlag og etiske standarder. For socialrådgiveres vedkommende handler det bla. om at sikre social velfærd og social retfærdighed for udsatte grupper. Dette definerer det sociale arbejdes særlige opgave eller mission i modsætning til mere bredt definerede opgaver, som kan deles af mange andre individer i en organisation. I Mads-sagen blev en del af "værdidagsordenen" sat af den kommunale rådmands henvisning til værdierne troverdighed, respekt og engagement (forkortet TRE!), som efter en lang, kompliceret proces blev vedtaget som de grundlæggende værdier for Århus Kommune. Men casen illustrerer, at sådanne moralske værdier i bedste fald er intetsigende, hvis de ikke i forhold til konkret sagsbehandling forankres i professionsetiske grundværdier, der angiver præcis, hvilke grundlæggende menneskelige goder det fx gælder om at være troværdig og engageret $\mathrm{i}$ forhold til..$^{5}$ Som antydet i indledningen kan man i høj grad betvivle, om man i behandlingen af Mads (og i hele anbringelsespolitikken) fremstod troværdigt, men det er ikke sagens kerne. Sagens kerne er den lidelse og mistrivsel, det konkrete barn blev udsat for, og det er her, den sociale indsats ifølge det etiske professionsbegreb må lægge sit fokus.

Den ovenfor nævnte "fremtrædende etiske dimension" kan i lyset af dette antage mange former, og det er ikke altid lige klart, hvilken forståelse af etik og dermed etiske værdier, der ligger bag etiske kodekser og retningslinjer. For at få et klarere greb om dette vil jeg her stipulere en sondring mellem etiske og moralske værdier. Der er ganske vist ikke nogen alment accepteret klar sondring mellem etik og moral. Nogle gange bruges "moral" om 1. ordens normer for rigtig eller forsvarlig opførsel og handling, mens etik er en 2. ordens undersøgelse eller begrundelse af moralen (dvs. etik som moralfilosofi). Jeg vil imidlertid i stedet benytte mig af en sondring, som er blevet gjort gældende med en vis vægt af bl.a. Bernard Williams og Ronald Dworkin (Williams 1985; Dworkin 2011). Det synes nemlig oplagt, at vi i mange sammenhænge - ikke mindst i professionsudøvelse - gør to væsensforskellige normative forestillinger gældende. Den ene angår, hvad der gør et liv godt eller værd at leve, mens den anden angår den rette handlemåde over for andre mennesker.

Nogle værdier angiver således mål eller idealer for, hvad der får en persons liv til at gå godt, dvs., hvad der gør et liv godt for den, hvis liv det er. De er værdier, for så vidt de bidrager til eller er elementer i et godt liv eller i 'velvære' forstået som 'god væren' eller vellykket livsudfoldelse. ${ }^{6}$ Disse kan passende kaldes etiske værdier i en mere specifik betydning, fordi betegnelsen 'etik' i sin oprindelige betydning hos Aristoteles netop satte ideen om det gode liv (eudaimoni) i centrum - etik var for Aristoteles simpelt hen opskriften på et godt eller vellykket liv (Aristoteles 2005). 
Moralske værdier angiver derimod mål eller idealer for, hvad vi skylder hinanden i medmenneskelig forstand. ${ }^{7}$ De er værdier, for så vidt de bidrager til eller er elementer i moralsk rigtig opførsel over for andre mennesker. ${ }^{8}$ Nærliggende eksempler på sådanne moralske værdier er omsorg og respekt: De angiver moralsk prisværdige holdninger til og behandling af andre mennesker. I Kants etik anses de moralske værdier for at være helt uafhængige af de etiske værdier: Vi kan indse, hvad moralsk opførsel kræver af os, hvad der er moralsk rigtigt, uafhængigt af hvad der i etisk forstand er godt (Kant 1785). Jeg vil over for dette hævde, at professionsetik må indebære en langt stærkere forbindelse mellem de etiske og moralske værdier.

Det faktum, at professionsetik er lige så gammel som de klassiske professioner selv, har at gøre med begge: Såvel de etiske som de moralske dimensioner er essentielle i disse professioner, og deres udøvere skal typisk offentligt erklære sig indforståede med og bundet af dem gennem en rituel aflæggelse af en ed eller et løfte, fx lægeløftet. Ordet profession er slet og ret dannet af latin profiteri - at afgive en offentlig erklæring (oprindelig det løfte, man tilbage til middelalderen aflagde, før man kunne indtræde i de katolske munkeordener). På engelsk er to profess at erklære noget på en forpligtende måde, at bekende sig til noget. Dette er også, hvad Koehn sigter til med "legitimating public pledge" i citatet ovenfor.

Nogle værdier i sådanne professionsetiske erklæringer er moralske og afspejler det faktum, at professionens klienter er i en særlig udsat eller sårbar position, når de søger professionel hjælp og støtte. Ydermere sidder professionsudøveren inde med en specialiseret viden, som klienten ikke er i en position til at opnå ved egen kraft. Klienter har derfor behov for en stærk bekræftelse af professionsudøverens troværdighed: at hun faktisk besidder de fagprofessionelle kvalifikationer og en veludviklet sans for sit særlige moralske ansvar. Den ældste professionsetiske kodeks, nemlig den hippokratiske læge-ed (ikke at forveksle med det danske lægeløfte!) tjente dette formål. Professionen gjorde sine moralske værdier offentligt kendt, således at man simpelt hen vidste, hvad man kunne regne med, når man opsøgte en autoriseret læge: at han ikke ville give ens inderste, intime hemmeligheder til bedste i festligt lag, at han ville afholde sig fra stærkt risikable indgreb osv. ${ }^{9}$

Disse moralske værdier er selvsagt af største vigtighed, men de udpeger ikke de klassiske professioners særlige etik. Mange andre erhverv kalder også på stærke moralske reguleringer, $\mathrm{fx}$ fordi de kan påføre stor risiko og skade, hvis de udøves lemfældigt - ingeniørkunst er et nærliggende eksempel. Det særlige ved de klassiske professioner er, at deres grundlæggende opgave knytter sig til essentielle elementer i et godt liv, dvs. til etiske værdier. De etiske værdier er således i en stærk forstand interne, fordi selve professionens kerneydelse tjener til at fremme en etisk værdi (Airaksien 1995). En bestemt professions unikke værdigrundlag er derfor, vil jeg hævde, etisk, ikke moralsk. Uheldigvis har de etiske værdier været noget overset i megen professionsetik, hvor der i stedet har været fokus på moralske principper (også selv om de er blevet kaldt etiske). Et nærliggende eksempel er de fire principper for biomedicinsk etik formuleret af Beauchamp \& Childress: Respekt for autonomi, godgørenhed, ikke-skadevolden og retfærdighed (Beauchamp \& Childress 2009). At sådanne principper ofte har været kritiseret for at være for 
vage, generelle og uforpligtende skyldes for mig at se, at de moralske principper har behov for etiske værdier og i sidste ende en vision om det gode liv for at give dem fokus og retning. En professionsetik må nødvendigvis have begge ben at gå på, dvs. både etiske grundværdier og moralske grundprincipper, og en underbetoning af det ene gør professionen halt. Godgørenhed er for eksempel et moralsk princip, der pålægger os en forpligtelse til at gøre godt og hjælpe andre mennesker. Men hvordan? Svaret bliver først tilnærmelsesvis klart, når vi bringer etiske værdier ind i overvejelserne. Sundhed er fx en ubetvivlelig etisk værdi. Alvorlige sundhedsproblemer er en forhindring for et godt liv. Så vi har en specifik pligt til at hjælpe mennesker med helbredsproblemer og gøre godt i forhold til folks helbred. Ja, her har vi endda en pligt til at sikre en professionel hjælp. Dette bringer os, vil jeg mene, til kernen i den etiske læsning af de klassiske hjælpeprofessioner.

\section{De etiske professioners grundværdier}

Lægegerningen og sagførergerningen har status som de klassiske hjælpeprofessioner. ${ }^{10}$ Siden antikken har de været omgærdet af en særlig aura, fordi de på hver sin måde har det som sin primære mission eller kerneydelse at hjælpe mennesker ud fra en professionel faglighed: Med lægekunsten kan man hjælpe mennesker ramt af sygdom, og med jurisprudensen kan man hjælpe mennesker under retsforfølgelse. Siden antikken har bestemte vejlederfunktioner, især pædagogik, psykologi og socialrådgivning, opnået samme status, om end på en lidt anden baggrund. Især pædagoger, men også psykologer og socialarbejdere, har i lighed med sygeplejersker traditionelt været betragtet som kaldede til deres gerning. I modsætning til præsters ydre kald enten fra Gud eller fra en menighed tænkes pædagoger og sygeplejersker at være mødt af et indre kald: Nogle menneskers psykiske konstitution er simpelthen sådan, at de føler en stærk trang til at have med udsatte mennesker at gøre. Med til dette billede hører i øvrigt, at disse beskæftigelser traditionelt (og aktuelt) er lavtlønsområder, og én forklaring ligger lige for: Hvis de pågældende alligevel ikke kan lade være med at udøve deres barmhjertigheds- og hjælpegerninger, behøver de ikke nogen videre belønning for dem - de bærer vel lønnen i sig selv! På den baggrund har "professionalisering" været en strategi med henblik på at løfte fagets status, herunder ikke mindst dets aflønning, gennem en vis distancering til kaldsopfattelsen.

Ifølge den etiske læsning kan man med pædagogikken og lærergerningen - i kraft af en særlig professionel faglighed - hjælpe børn til dannelse og værdifuld udvikling. Med psykologien kan man - i kraft af en anden særlig professionalisme - hjælpe mennesker med psykiske lidelser, således at de igen får mulighed for indre autonomi (frem for at være fremmedbestemt af deres psykiske lidelse). Og med professionelt socialt arbejde kan man hjælpe mennesker med sociale problemer, så de bliver i stand til at opnå social velfærd og ligeværdig social status.

Helt overordnet er baggrunden, at mennesker, i kraft af de basale behov, de nu engang har, er $u d s a t t e$ eller sårbare i bestemte henseender, og hvis ikke man kan få hjælp i sådanne udsatte situationer, forspildes muligheder for at leve et godt liv (Alexandra \& Miller 
2009). Mange af de problemer, vi gennem livet løber ind i, kan vi ved at strenge os an klare selv. Men det synes at være et menneskeligt vilkår, at mange andre problemer $i k k e$ klares uden andres hjælp. Hvis man ikke hjælpes til en værdifuld udvikling som barn, hvis ikke man hjælpes, når man bliver syg, hvis ikke man får hjælp, når man sigtes, anklages og retsforfølges, hvis man ikke hjælpes gennem psykiske kriser og lidelser, hvis ikke man får bistand, når man ikke kan forsørge sig og sine - ja, så bliver man afskåret fra helt basale menneskelige goder: livsduelighed, fysisk sundhed, retfærdighed, indre selvstyre og social velfærd.

Sammenfattende kan de etiske professioner således - lettere skematisk - primært identificeres og skelnes fra hinanden i kraft af deres kerneydelse og grundværdi: ${ }^{11}$

\begin{tabular}{|c|c|c|}
\hline Profession & Kerneydelse & Grundvardi(er) \\
\hline Lægekunst & Sygdomsbehandling & Raskhed/sundhed \\
\hline Advokatgerning & Retslig bistand & Retssikkerhed \\
\hline Lærergerning & Undervisning, læring & $\begin{array}{l}\text { (Ud)dannelse, } \\
\text { livsduelighed }^{12}\end{array}$ \\
\hline Psykologi & Behandling af psykiske lidelser & Indre selvstyre \\
\hline Socialt arbejde & Social rådgivning & $\begin{array}{l}\text { Velfærd, } \\
\text { social retfærdighed }^{13}\end{array}$ \\
\hline Pædagogik $^{14}$ & $\begin{array}{l}\text { Omsorg, socialisering, dannel- } \\
\text { se og læring }\end{array}$ & Trivsel og udvikling \\
\hline
\end{tabular}

Skemaet er selvsagt ikke endegyldigt, men alene ment som en angivelse af, hvordan en professionsidentitet kunne afdækkes ud fra den etiske læsning.

Det ovenstående forklarer også, hvorfor de nævnte professioner må være baserede ikke bare på en etik, men også en filosofi. Deres grundværdi og dermed deres kerneydelse er nemlig langt fra selvforklarende. På spørgsmål som "hvad er sundhed?", "hvad er retfærdighed?" og "hvad er velfærd?" har de færreste svar på rede hånd, og at have det er snarere udtryk for en vis indskrænkethed end uforligelig intelligens. ${ }^{15}$ Man kan ligefrem hævde, at disse begreber er "essentielt omstridte", dvs. at de i kraft af deres natur så at sige med nødvendighed må give anledning til stridende fortolkninger, og at vi simpelthen har misforstået dem, hvis vi tror eller håber, at vi engang får formuleret teorien om sundhed eller retfærdighed. ${ }^{16}$ De kalder derfor på filosofiske analyser og refleksioner med henblik på trods alt at gøre dem nogenlunde håndterlige og formulere visse velbegrundede antagelser om sundhed, retfærdighed osv. Dette er baggrunden for, at vi har veletablerede discipliner som medicinsk filosofi, retsfilosofi og pædagogisk filosofi (men ikke fx blikkenslagerfilosofi eller postomdelingsfilosofi).

Findes der et (endnu) dybere kriterium for at tildele de klassiske hjælpeprofessioner deres særstatus? Spørgsmålet bliver naturligvis relevant i det øjeblik andre faggrupper 
stiller sig $\mathrm{i}$ kø for at blive anerkendt som professioner i denne forstand: Kan de på plausibel vis hævde, at deres kerneydelse knytter sig til etiske grundværdier? Nuvel, kriteriet er nævnt tidligere: Sundhed, retfærdighed, livsduelighed, indre selvstyre samt velfærd og social retfærdighed er basale menneskelige goder, idet de er væsentlige for at få et godt liv. I alle etiske professioner er der således impliceret en teori, der hævder, at den pågældende grundværdi uomgængeligt hører det gode menneskeliv til. ${ }^{17}$ Set i det lys knytter sygepleje måske nok an til den samme etiske grundværdi som lægevidenskaben (sundhed eller raskhed), men sygeplejersker kan med god ret hævde, at de faktisk har en distinkt kerneydelse i forhold til lægegerningen, nemlig pleje, trøst og lindring af syge og lidende, en ydelse, lægerne ofte er relativt uformående til at levere. Jeg har selv i anden sammenhæng argumenteret for, at ergoterapi er en etisk profession med aktivitet og deltagelse i (hverdags)livet som både etiske grundværdier og kerneydelse, idet målet om et liv præget af aktivitet og deltagelse (den etiske grundværdi) søges optrænet gennem støtte og facilitering af patientens deltagelse i egne hverdagsprægede aktiviteter (professionens kerneydelse) (Dige 2009). Ligeledes anser jeg hospicepleje som professionsudøvelse med pleje af døende som en distinkt kerneydelse og den gode død som en etisk grundværdi. Selv om det kan lyde som et paradoks er en god død et essentielt element i et godt liv (Dige 2012).

Professioner er altså ifølge den etiske læsning de fag eller gerninger, der har en særlig identitet ved på plausibel vis at være forankrede i etiske grundveerdier. Disse værdier skal for det første være professionen iboende og medvirke til, at den fremstår som en samlet enhed; der er ikke blot tale om nogle udefrakommende etiske krav, som man mere eller mindre modstræbende bøjer sig for. Og for det andet skal den enkelte professionsudøver have gjort grundværdierne til en indgroet del af sin personlighed. Grundværdierne skal m.a.o. samtidig være $d y d e r$ : erhvervede, fast forankrede karaktertræk (Oakley \& Cocking 2001). De etiske professioner kan strengt taget kun udøves af mennesker, som ud over de nødvendige faglige kvalifikationer samtidig besidder bestemte menneskelige egenskaber. Traditionelt har man også signaleret dette ved at professionsudøvere skam ikke modtog noget så profant som løn, men derimod blev honoreret! Dette er som bekendt i modsætning til fag, hvor der ikke i ret vid udstrækning arbejdes med mennesker. Man kan $\mathrm{fx}$ snildt være en dygtig blikkenslager og relativt inkompetent, hvad angår medmenneskelige egenskaber, mens noget sådant gør det umuligt at udføre en etisk profession godt. Dårlige professionsudøvere vurderes i det lys: Vi har sikkert alle haft lærere i folkeskolen eller mødt læger, der hellere skulle have været blikkenslagere eller lignende. ${ }^{18}$

\section{De tre au'er}

Det er karakteristisk for de klassiske professioner, at de har en stærk selvforståelse, der af og til kan slå ud i en form for selvtilstrækkelighed, en logelignende lukkethed mod omverdenen og paternalistisk bedrevidenhed over for patienter og klienter. Det vidner om, at professionsorienteringen indebærer en meget stærk måde at organisere det professionelle arbejde på, men den er ikke desto mindre kommet under stærkt pres de senere årtier - eller ligefrem "krydspres", idet én type pres er kommet "nedefra" fra mere eller 
mindre velorganiserede grupper af patienter og klienter, ${ }^{19}$ mens en anden er kommet "ovenfra" fra de organisationer, moderne professioner virker i, og den politiske forvaltning, som mere eller mindre detaljeret definerer rammerne for professionsudøvelsen.

Når man taler om professionsorienteringen peges der typisk på tre centrale elementer $\mathrm{i}$ denne, som jeg her kalder "de tre au'er" (de er i mangt og meget tæt forbundne med de fem kriterier for professionsstatus, som jeg nævnte på de første sider): ${ }^{20}$

1 Autorisation: Dette hænger sammen med en hævdelse af opgavernes komplekse og livsvigtige karakter, som gør, at de kun bør løftes af autoriserede personer med dokumenteret, videnskabeligt funderet viden og specialistkundskab ( $\mathrm{fx}$ autoriserede læger). Derfor skal uddannelses- og beskæftigelsesmonopolet opretholdes.

2 Autonomi: Opgavernes komplekse og dynamiske karakter tilsiger desuden, at den enkelte professionsudøver må have udstrakt frihed til selvstændig arbejdstilrettelæggelse. Fordi man arbejder med individuelle problemstillinger, er der ikke to opgaver, som er ens, og derfor kan man kun i begrænset udstrækning holde sig til standardprocedurer og standardbehandlinger. Der vil altid være et afgørende element af professionelt skøn i at finde frem til den rette håndtering af opgaven. Hvad der er den rette håndtering kan derfor strengt taget også kun bedømmes af fagkolleger og derfor opererer professionsorienteringen også med kollegial kvalitetssikring (peer review, supervision) og kollegiale sanktioner ved uetisk opførsel (fx ekskludering af professionsforeningen).

3 Autenticitet: Opgavernes etiske karakter, dvs. deres tilknytning til centrale livsgoder, gør det afgørende, at professionsudøveren på autentisk vis bekender sig til professionens grundværdier og etiske retningslinjer. Frem for alt må professionsudøveren fremstå som troværdig og tillidvækkende over for patienten/klienten ved i et og alt at ville handle til dennes bedste "uden persons anseelse" eller andre uvedkommende hensyn i forhold til opgaven. Professionsudøverens loyalitetspligt gælder altid først og fremmest patientens eller klientens bedste og først i anden omgang kolleger, organisationen og det omgivende samfund. ${ }^{21}$

Under velfærdsstatens og den offentlige sektors opbygning efter Anden Verdenskrig var professionsorienteringen stort set enerådende og de tre au'er stod uantastede. Siden 1980'erne er den offentlige sektors velfærdsinstitutioner imidlertid blevet gjort til genstand for en række reformer og reformforsøg under samlebetegnelsen New Public Management (NPM). Der er i virkeligheden tale om et antal meget forskellige rationaliseringsog effektiviseringsbestræbelser, som er skyllet ind over den offentlige sektor i flere bølger (se fx Klausen 2001; Larsen 2001; Melander 2008). Det vil vi ikke bevæge os længere ind $i$ her, men fokusere på et fremtrædende aspekt af NPM, som handler om anlæggelsen af en organisationsorientering eller (med Freidson 2001) organisationslogik på professionelt arbejde til erstatning for eller i det mindste modvægt til professionslogikken, og hvorledes dette kan præsentere en udfordring for sidstnævntes bastioner, de tre au'er (Engel \& Hjort 2006). 
Autorisationskravet kan blive sat under pres både eksternt og internt. Eksternt sker det, når uddannelses- og beskæftigelsesmonopolet udfordres gennem (forslag til) delegering af de professionelle ydelser til andre faggrupper, typisk med kortere uddannelser, svagere organisering og lavere løn. Rationaliseringer og effektiviseringer efterstræbes gennem en nedbrydning af faggrænser, krav om tværfaglighed m.v., som igen åbner for at nye faggrupper lige så godt kan løse de opgaver, som en bestemt profession har haft monopol på. I forbindelse med Mads-sagen kom det frem, at fratagelsen af socialrådgivernes bevillingskompetence medførte, at en del af sagsbehandlingen blev overtaget af ansatte uden for professionen, men socialrådgiverne skulle dog stadig eksekvere beslutningen:

Vi fik bare at vide, at vi skulle aflevere den og den sag, og så fik vi den og den besked, og det skulle vi så fortælle til folk. Der var ingen paragraffer med, og der var ingen klagevejledning. Der var ingenting, og det var os, der sad og skulle føre det ud i livet. Vi skulle gøre noget, som andre traf beslutninger om, og vi vidste ikke, hvorfor de havde gjort det, og det var dybt utilfredsstillende (anonym socialrådgiver, citeret i Kildedal 2009: 55).

Andre eksempler er SOSU-assistenters varetagelse af traditionelle sygeplejeopgaver eller forslagene om brug af forskere og specialister til undervisning i folkeskolens afgangsklasser ud fra en formodning om at de professions-specifikke pædagogiske og didaktiske kompetencer er mindre nødvendige på de højere klassetrin.

Internt presses autorisationskravet ofte vha. plus-ordet fleksibilitet, således at professionsudøveren skal være omstillingsparat og indstillet på at omdefinere sine opgaver og påtage sig nye dikteret udefra også selv om de ikke lige er dem, hun er uddannet og besidder specialistkompetencer til (se Sehested 1995: 119-131). Ofte med det resultat, at professionsudøveren kun i ringe grad kommer til at beskæftige sig med professionens kerneydelse. Dette forstærkes af krav om accountability, som søges imødekommet gennem en opdeling af de professionelle indsatser i sekventielle enkelthandlinger og en tilsvarende nedprioritering af processer og dialog mellem professionsudøver og klient, patient eller elev (Staugård 2009).

Autonomien opleves sammenhængende hermed også som presset af en række instrumenter til effektivisering og rationalisering: centralt fastlagte procedurer for opgaveløsning ( $\mathrm{fx}$ detaljerede procedurer for hjemmepleje), kontrakt- og resultatstyring (fx gennem udviklingskontrakter og akkrediteringskrav), organisationsorienterede succeskriterier ( $\mathrm{fx}$ hvordan organisationen klarer sig over for "konkurrenter"), ekstern kvalitetssikring af objektivt målbare ydelser (fx antallet af "liggedage" på sygehuse) m.v. Alt dette er noget, som efterlader betydeligt mindre plads til, at den enkelte professionsudøver løser opgaverne "efter bedste skønnende" (hvilket danske læger ellers har aflagt løfte om). Når professionsudøvere ikke ser decentralisering af det økonomiske og administrative ansvar som en $u d v i d e l s e$ af deres autonomi (pace Jespersen 1995), hænger det sammen med, at sådanne krav om prioriteringer så at sige ude ved sygesengen netop ikke styrker den professionelle autonomi, fordi den professionelle vurdering bliver "inficeret" af professionsfremmede hensyn, som i en mere klassisk arbejdsdeling blev varetaget af økonomiansvarlige andre steder i organisationerne. I Mads-sagen kom dette som nævnt gan- 
ske bastant til udtryk gennem kravene om at "føle ejerskab" for de økonomiske hensyn og fratagelsen af bevillingskompetencen, som må anses at være et væsentligt element $\mathrm{i}$ den professionelle autonomi. Socialrådgiverne blev dertil underlagt detaljerede og substantielle krav til deres indstillinger med det resultat, at det professionelle skøn i mange tilfælde blev meningsløst (kravet om altid at formulere et alternativ til anbringelse, også når det skønnedes ikke at være forsvarligt). Selv om professionsudøverne i en vis forstand fik mere udstrakt autonomi i kraft af decentralt medansvar for overholdelse af budgettet, var omkostningen således en drastisk indskrænkning i den professionelle autonomi.

Autenticiteten opleves tilsvarende under pres fra kravene om at tage overordnede organisationelle hensyn med ind i den konkrete opgaveløsning, $\mathrm{fx}$ ved at tage omkostningshensyn eller andre målrationaler med i betragtning i fx sagsbehandling eller pleje. Når professionsudøveren pålægges at anlægge en helhedsvurdering i forhold til en konkret sag, er der selvsagt ikke længere tale om at sætte klienten i centrum. Det omtalte krav om at "føle ejerskab" for sammenhængen mellem indsats og økonomi er i potentiel konflikt med en autentisk bekendelse til det klientcentrerede hensyn, fordi den lægger op til en "puljetænkning" hos den menige socialrådgiver med fare for, at hun eller han primært har blik for sagens økonomiske omkostninger frem for dens sociale og pædagogiske udfordringer. Noget sådant kunne vel tænkes at influere negativt på professionsudøverens troværdighed og klientens tillid til, at hun eller han vil én det bedste. Generelt gælder det ikke overraskende, at organisationsorienteringen indebærer et krav om loyalitet over for organisationen, således at man bidrager til, at den ikke stilles i et dårligt lys, men derimod performer bedst muligt i sammenligning med andre organisationer og i kampen om myndigheders og forvaltningers gunst.

Nedbrydningen af de tre bastioner er typisk gensidigt forstærkende. Nedbrydningen af autorisationsbetingelsen med dens stærke professionelle organisering gør det fx indlysende nok sværere for professionerne at værne om den professionelle autonomi og autenticitet. Der er næppe tvivl om, at "uautoriserede" medarbejdere med en svagere faglig forankring vil være mere tilbøjelige til at acceptere sådanne uetiske eller endog lovstridige direktiver. I Mads-sagen blev socialrådgiverne som nævnt stillet i dette næsten arketypiske loyalitetsdilemma, og her udtalte én af dem følgende:

I den periode havde jeg to sager, der efter min vurdering var klare anbringelser, og dem fik jeg nej til. De sager blev anket - den ene ankede jeg, og jeg fik klokkeklar besked [fra ankestyrelsen] om, at det var en anbringelse. Og der mener jeg, at der er forskel på at være gammel og ny i faget i forhold til at gå op imod systemet (anonym socialrådgiver, citeret i Kildedal, 2009: 55).

Tilsvarende er pointen selvfølgelig, at en professionel oprustning i den etiske læsnings perspektiv må handle om en samlet styrkelse af alle de tre au'er, netop fordi de må forstås som gensidigt understøttende. 


\section{Konklusion}

Den aktuelle "etikbølge" i professionsuddannelser og professionsudøvelse er et sammensat fænomen med en række højst forskellige motiver og målsætninger. Jeg har fremhævet nogle væsentlige skillelinjer i vurderingen af disse. Den etiske læsning af hjælpeprofessionerne udpeger for det første en problemfyldt spænding mellem professions- og organisationslogikken, hvor formulering af etiske værdier spiller vidt forskellige roller som hhv. identitetskonstituerende og regulerende instans. For det andet motiverer den et fokus på (og stadig udforskning af) etiske værdier i aristotelisk forstand, dvs. konstitutive elementer i et godt liv - i særdeleshed sådanne, som kun kan opretholdes og fremmes med passende professionel hjælp. For det tredje udpeger den de centrale professionsmarkører, autorisation, autonomi og autenticitet som afgørende for etisk forsvarlig professionsudøvelse og problematiserer dermed det målrationelle organisationsparadigmes svækkelse af disse tre au'er.

\section{Tak til}

Jeg skylder to kolleger, Jørgen Husted og Torben E. Andreasen, en stor tak for mange diskussioner og deres publikationer om professionsetik, som har været en væsentlig inspiration for denne artikel. Det samme gælder de mange inputs, jeg gennem en årrække har modtaget fra de erfarne og tænksomme kursister på Master i Etik og Verdier i Organisationer ved Aarhus Universitet.

\footnotetext{
Noter

${ }^{1}$ Case-beskrivelsen baserer sig primært på den detaljerede udredning i Kildedal 2009.

2 I dansk sammenhæng gælder det bl.a. Dansk Sygeplejeråd ("Sygeplejeetiske retningslinjer" 2004), Ergoterapeutforeningen ("Professionsgrundlag for ergoterapi" 2008), Danske Bioanalytikere ("Bioanalytikernes fagetiske univers" 2008), Socialpædagogernes Landsforbund ("Etisk værdigrundlag for socialpædagoger" 2010), Jordemoderforeningen ("Etiske retningslinjer for jordemødre" 2010), Dansk Socialrådgiverforening ("Professionsetik" 2011). Alle disse kan findes på de pågældende foreningers hjemmesider.

${ }^{3}$ Det danske lægeløfte afspejler ganske tydeligt disse elementer og den centrale placering af den etiske dimension: "Efter at have aflagt offentlig prøve på mine i de medicinsk-kirurgiske fag erhvervede kundskaber, aflægger jeg herved det løfte, til hvis opfyldelse jeg ydermere ved håndsrækning har forpligtet mig, at jeg ved mine forretninger som praktiserende læge stedse skal lade det være mig magtpåliggende, efter bedste skønnende, at anvende mine kundskaber med flid og omhu til samfundets og mine medmenneskers gavn, at jeg stedse vil bære lige samvittighedsfuld omsorg for den fattige som for den rige uden persons anseelse, at jeg ikke ubeføjet vil åbenbare, hvad jeg i min egenskab af læge har erfaret, at jeg vil søge mine kundskaber fremdeles udvidede og i øvrigt gøre mig bekendt med og nøje efterleve de mig og mit fag vedkommende anordninger og bestemmelser." Se Andreasen 2005 for en udførlig diskussion af lægeløftets professionsværdier.

${ }^{4}$ WMA Declaration of Tokyo, Declaration of Istanbul, Declaration of Hamburg: http://www.wma.net/ en/20activities/10ethics/20tokyo/; Resolution of Lisbon: http://www.wma.net/en/30publications/ 10policies/c1/
} 
${ }^{5}$ Ret beset kan hverken troværdighed eller engagement tilskrives egenværdi al den stund Adolf Hitler i eminent grad levede op til begge. De er, hvad jeg vil betegne som faciliteringsvoerdier, dvs. de er værdier, for så vidt de er faciliterende for genuine etiske grundværdier.

${ }^{6}$ De dominerende teorier om velvære er fremstillet og diskuteret i bl.a. Griffin 1986: part I, og Dige 2003: kap. 3.

${ }^{7}$ Formuleringen "hvad vi skylder hinanden" er hentet fra Thomas Scanlons hovedværk What We Owe to Each Other, som netop er en undersøgelse med fokus på moralske værdier.

${ }^{8}$ Jeg finder ikke her grund til at tage et andet interessant spørgsmål op, nemlig hvilke andre væsener end mennesker, vi evt. har en større eller mindre moralsk skyldighed over for. Hvis det var dyrlægers professionsetik, der var til diskussion, ville det selvsagt blive et helt centralt spørgsmål.

${ }^{9}$ Dansk oversættelse af den hippokratiske ed findes bl.a. i Gyldendals åbne encyklopædi: http:// www.denstoredanske.dk/Krop,_psyke_og_sundhed/Sundhedsvidenskab/L\%C3\%A6ger/Hippokrates

${ }^{10}$ Præstegerningen har siden middelalderen også hørt til de klassiske professioner. Med forbehold for mine begrænsede teologiske kundskaber er det mit indtryk, at præster i kristne kirker (katolske såvel som protestantiske) i moderne tid i stigende grad har haft den "vandrette" relation til noesten (i form af sjælesorg, åndelig vejledning m.v.) som relativt fritstående fokus i forhold til den "lodrette" relation til Gud. I den forstand indeholder præstegerningen i det mindste elementer af relationsprofession.

${ }^{11}$ For de tre første professioners vedkommende følger jeg Carr 2000: kap. 2.

12 Se Husted 2002, for en mere udførlig redegørelse for lærergerningens professionsetik.

${ }^{13}$ Se Reamer 2006 for en detaljeret udfoldelse af det sociale arbejdes værdigrundlag.

${ }^{14}$ Se "Etisk grundlag for pædagoger", Børne- og Ungdomspædagogernes Landsforbund (BUPL), http:// www.bupl.dk/iwfile/BALG-95YGRS/\$file/EtiskGrundlag_2011.pdf.

${ }^{15}$ Spørgsmålet "hvad er retfærdighed?" er temaet for den vestlige filosofis første hovedværk, Platons: Staten. Det er stadig et åbent spørgsmål og er ikke blegnet i betydning siden.

${ }^{16}$ Ideen om "essentially contested concepts" blev lanceret af W.B. Gallie i en artikel med samme titel i Proceedings of the Aristotelian Society, 56 (1956), 167-198.

${ }^{17}$ For god ordens skyld skal det nævnes, at en sådan etisk redegørelse for de klassiske hjælpeprofessioner og deres værdier ikke står alene. Alternative bud på eksempelvis socialt hjælpearbejde kunne være, at det primært er en kapitalistisk økonomis lapperi på destabiliserende social ulighed og elendighed (marxis$\mathrm{me}$ ); at det blot er en raffineret form for kontrol, undertrykkelse og disciplinering (Foucault); at det blot er en illegitim statslig indgriben i de frie markedsmekanismer og/eller udslag af socialstatslig slavementalitet (laissez faire-liberalisme). Alle disse alternativer stiller selvsagt professionsudøvelsen i et helt andet - i mine øjne højst uplausibelt - lys.

${ }^{18}$ Jeg har intet udestående med VVS-branchen; pointerne her tjener alene et illustrerende sigte.

${ }^{19}$ Et godt udtryk for denne tendens er bogen No Longer Patient af Susan Sherwin (Temple University Press, 1992).

${ }^{20}$ De tre au'er nævnes eksplicit i Engel \& Hjort 2006, men er som nævnt implicit til stede i de fleste bud på "professionsmarkører" i litteraturen, fx Airaksinen 1994; Carr 2001; Staugård 2011.

${ }^{21}$ Det er ikke alle professioner, der scorer højt på alle tre parametre. Børne-og ungdomspædagoger scorer således (i Danmark) ret lavt på autorisation/monopol, men højt på autonomi, hvor det hos sygeplejersker forholder sig omvendt. Men kamp om anerkendelse som profession handler så også typisk om at udfordre sådanne begrænsninger på au'erne.

\section{Litteratur}

Airaksinen, T. (1994) Service and Science in Professional Life. I Ethics and the Professions, red. R. F. Chadwick, s. 1-13. Aldershot: Avebury. 
Alexandra, A. \& Miller, S. (2009) Ethical theory, "common morality", and professional obligations. Theoretical Medicine and Bioethics, 30, s. 69-80.

Andreasen, T. E. (2005) Lægeløftets etik. I: Etiske spørgsmål i medicinen, red. M. K. Skadborg, T. E. Andreasen \& K. Bertelsen, s. 11-31. København: FADL's forlag.

Aristoteles (2005) Etikken. København: Det lille forlag.

Beauchamp, T. L. \& Childress, J. F. (2009) Principles of Biomedical Ethics (6 ${ }^{\text {th }}$ ed.). Oxford: Oxford University Press.

Carr, D. (2000) Professionalism and Ethics in Teaching. London: Routledge.

Dansk Socialrådgiverforening (2000) Etikvejledning - etiske principper i social arbejde. Tilgået 21.8.2014 fra: http://ifsw.org/publications/national-codes-of-ethics/ dasw-code-of-ethics/

Dige, M. (2003) Det gen-skabte menneske. København: Munksgaard.

Dige, M. (2009) Occupational therapy, professional development and ethics. Scandinavian Journal of Occupational Therapy, 16 (2), s. 88-98.

Dige, M. (2012) Etik og succeskriterier i hospicepleje. Social Kritik, maj 2012, s. 82-91.

Dworkin, R. (2011) Justice for Hedgehogs. Cambridge, Mass.: Harvard University Press.

Engel, S. \& Hjort, K. (2006) Internationalisering og professionalisering. København: BUPL's forlag.

Evetts, J. (2006) Trust and Professionalism: Challenges and Occupational Changes. Current Sociology, 54 (4), s. 515-531.

Evetts, J. (2011) Sociological Analysis of Professionalism: Past, Present and Future. Comparative Sociology, 10, s. 1-37.

Fournier, V. (1999) The appeal to 'professionalism' as a disciplinary mechanism. The Sociological Review, 47 (2), 280-307.

Freidson, E. (2001) Professionalism: The Third Logic. London: Polity Press.

Freidson, E. (2003) Comments on JHPPL Review Symposium. Journal of Health Politics, Policy and Law, 28 (1), s. 168-172.

Griffin, J. (1986) Well-Being: Its Meaning, Measurement, and Moral Importance. Oxford: Clarendon Press.

Grimen, H. (2008) Profesjon og profesjonsmoral. I: Profesjonsstudier, red. A. Molander \& L.I. Terum, s. 144-160. Oslo: Universitetsforlaget.

Husted, J. (2002) Professionsetik og lærergerning - et baggrundpapir. København: Danmarks Lærerforening. Tilgået 21.8.2014 fra: http://www.dlf.org/media/43 429/ professionsetikoglaerergerning.pdf

Husted, J. (2013) Etik og voerdier i sygeplejen. København: Hans Reitzel.

IFSW (International Federation of Social Work) (2012) "Statement of Ethical Principles". Tilgået 19.8.2014 fra: http://ifsw.org/policies/statement-of-ethical-principles/

Jespersen, P. K. (1995) De professionelle, fagbureaukratiet og omstilling i den offentlige sektor. I: Sociale organisationer i en omstillingstid, red. T. U. Bømler, s. 75-97. København: Munksgaard/Rosinante.

Johansen, M. B. \& Olesen S. G. (red.) (2011) Professionernes sociologi og vidensgrundlag. Aarhus: Via Systime. 
Kildedal, K. (2009) Undersøgelse af den socialfaglige praksis - i anbringelsessager og sager med omfattende hjælpeforanstaltninger i Århus Kommune, første delrapport november 2008. Institut for Sociologi, Socialt arbejde og Organisation, Ålborg Universitet. Tilgået 10.6.2014 fra: http://vbn.aau.dk/files/31 925 236/Undersøgelse\%20\%20Århus\%20Kommune.pdf

Klausen, K. K. (2001) Skulle det vare noget sarligt? Organisation og ledelse i det offentlige. København: Børsens Forlag.

Koehn, D. (1994) Ground of Professional Ethics. London: Routledge.

Larsen, Ø. (2001) Etik og moderne refleksiv ledelse i den offentlige forvaltning. I: Etik til debat: verdier og etik i den offentlige forvaltning, red. A. Berg-Sørensen, s. 37-59. København: Jurist- og økonomforbundets forlag.

Luban, D. (2003) Professional Ethics. I: A Companion to Applied Ethics, red. R. G. Frey \& C. H. Wellman, s. 583-596. Malden, MA: Blackwell.

Melander, P. (red.) (2008) Det fortrcengte offentlige lederskab: Offentlig ledelse efter New Public Management. København: Jurist- og Økonomforbundets forlag.

Oakley, J. \& Cocking, D. (2001) Virtue Ethics and Professional Roles. Cambridge: Cambridge University Press.

Reamer, F. (2006) Social Work Values and Ethics ( $3^{\text {rd }}$ Ed.). New York: Columbia University Press.

Scanlon, T. (1998) What We Owe to Each Other. Cambridge, Mass.: Harvard UP.

Sehested, K. (1995) Professioner og offentlige strukturcendringer. København: AKF-forlaget.

Socialministeriet (2003) Redskaber til styring af indsatsen vedrørende udsatte børn og unge. Tilgået 10.6.2014 fra:

http://195.41.32.55/domino/jur/jurdags2.nsf/d6c8285b91 498b164 125 662c0042f76a/ ee29 878653 805a7cc12 575b7003e1401/\$FILE/Redskaber\%20til\%20styring\%20af\% 20indsatsen\%20vedr._441qm8sr1ehq6a832jdp6s83fcsg7arj7ck_.pdf

Staugård H. J. (2009) Hvad er professioner og hvad kan de udvikle sig til? Videnscenter for professionsudvikling. Aalborg: University College Nordjylland.

Staugård H. J. (2011) Professionsbegrebet. I: Professionernes sociologi og vidensgrundlag, red. M. B. Johansen \& S. G. Olesen, s. 161-175. Aarhus: Via Systime.

Williams, B. (1985) Ethics and the Limits of Philosophy. Cambridge: Cambridge University Press.

Århus Kommune (2008) Svar fra Århus Kommune i sagen om Mads. TV2 (Danmark). Tilgået 10.6.2014 fra: http://programmer-dyn.tv2.dk/dok/article.php/id-11 227 687:svarfra-\%C3\%A5rhus-kommune-i-sagen-om-mads.html 